\title{
The impact of hive type on the behavior and health of honey bee colonies (Apis mellifera) in Kenya
}

\author{
Alexander McMenamin ${ }^{1,2}$, Fiona Mumoki ${ }^{3}$, Maryann Frazier ${ }^{1}$, Joseph Kilonzo ${ }^{3}$, \\ Bernard Mweu ${ }^{4}$, Tracey Baumgarten ${ }^{1}$, Harland PATCH ${ }^{1}$, Baldwyn Torto ${ }^{3}$, \\ Daniel Masiga ${ }^{3}$, James Tumlinson ${ }^{1}$, Christina Grozinger $^{1}$, Elliud Muli ${ }^{5}$ \\ ${ }^{1}$ Department of Entomology, Center for Pollinator Research, Pennsylvania State University, University Park, PA, USA \\ ${ }^{2}$ Department of Microbiology and Immunology, Pollinator Health Center, Montana State University, Bozeman, MT, USA \\ ${ }^{3}$ The International Centre of Insect Physiology and Ecology (icipe), P.O. Box 30772-00100, Nairobi, Kenya \\ ${ }^{4}$ Department of Physical Sciences, South Eastern Kenya University, P.O. Box 170-90200, Kitui, Kenya \\ ${ }^{5}$ Department of Biological Sciences, South Eastern Kenya University, P.O. Box 170-90200, Kitui, Kenya
}

Received 20 December 2016 - Revised 11 April 2017 - Accepted 26 April 2017

\begin{abstract}
There has been a long-standing interest in developing approaches to maximize honey production by Kenyan beekeepers. Since honey bees in Kenya are passively managed, the main decision beekeepers make is which hive type to use: traditional Log hives, Langstroth hives, and Kenyan top-bar hives. We found Langstroth hives to be the most attractive to migrating swarms, followed by Log hives, while Kenyan top-bar hives were the least preferred. Pathogen and parasite loads correlated only with colony age and absconding rates were associated only with colony size and weight. We recommend additional studies to understand the factors that drive swarm attraction to hive bodies and highlight practical concerns about Kenyan top-bar hives that need to be addressed to improve their utility to beekeepers. Also, placing apiaries in areas with floral resources may reduce absconding rates; however, periodic breaks in brood production may serve as a mechanism to reduce parasite and pathogen loads.
\end{abstract}

\section{apiculture / management practices / pathogen / rural beekeeping / absconding}

\section{INTRODUCTION}

In East Africa, honey bees (Apis mellifera) provide critical pollination services, nutrition, and income for smallholder farmers and rural families. Honey bees and other pollinators contribute

Electronic supplementary material The online version of this article (doi:10.1007/s13592-017-0515-5) contains supplementary material, which is available to authorized users.

Corresponding author: C. Grozinger,

cmgrozinger@psu.edu;

E. Muli, emuli@icipe.org

Alexander McMenamin and Fiona Mumoki contributed equally to this work.

Manuscript editor: Stan Schneider
US\$3.2 million in ecosystem services to several major vegetable, fruit, and nut crops in western Kenya alone (Kasina et al. 2009). Honey produced by both honey bees and several stingless bee species provides nutrition (particularly during times of drought) and income for many East Africans and has important cultural and medicinal value (Macharia et al. 2010; National Farmers Information Service of Kenya). Populations of honey bees in East Africa are essentially wild: empty hives are occupied by migrating honey bee swarms, and beekeepers typically only disturb colonies at the time of honey collection, after which colonies abscond (cease brood rearing, consume all food stores, and abandon the hive) and migrate to a new location (Crane 1999; Mbae 1999). Thus, the choice of hive type is the primary management 
Figure 1. Honey bee hive types commonly used in East Africa. a Langstroth hives. These are most commonly used in Western beekeeping. Contrary to typical Western practices, in Kenya, these hives are often suspended from a tree or bar as shown. b Kenyan top-bar hives. These hives are also suspended from a tree limb to dissuade predators. The comb has no support structure and consists only of a bar at the top of the hive body from which the bees build comb. c Traditional Log hives. This hive body is most commonly used in Kenyan beekeeping because they are inexpensive, longlasting, and easy to maintain. These hives vary considerably in size as they are simply cut, hollowed-out logs, but the volumes of the hives are usually intermediate between the Langstroth and Kenyan top bar. (Photos from Maryann Frazier).

decision made by the majority of beekeepers. East African beekeepers typically use three hive styles: traditional Log hives, which have fixed combs as in a wild colony; Langstroth hives, which are the typical Western-style hive with movable frames; and the Kenyan top-bar (KTB) hive, which employs movable top bars rather than frames (see Figure 1 for details about hive types, and reviewed in (Adjare 1990)).

In an effort to improve the livelihoods of rural people in East Africa, several beekeeping development projects over the last 50 years have introduced Western-designed equipment (Langstroth and KTB hives) that increases the capacity of beekeepers to actively manage their colonies and, ideally, increase honey production. Recommendations from government agencies and extension personnel, non-profit development groups, and academic researchers have nearly universally stated that Kenyan beekeeping would benefit from adoption of modern movable-comb hives (Adjare 1990; Ntenga and Mgongo 1991; UNDP-Kenya 2008; Wilson 2006). However, locally produced Langstroth hives are often of poor construction and beekeepers often receive little instruction on how to manage these hives. This has resulted in poor performance and eventual abandonment (Muli et al. in review). Furthermore, compared to Log hives (\$4-10), the high cost of Langstroth (\$50-70) and KTB (\$40) hives puts
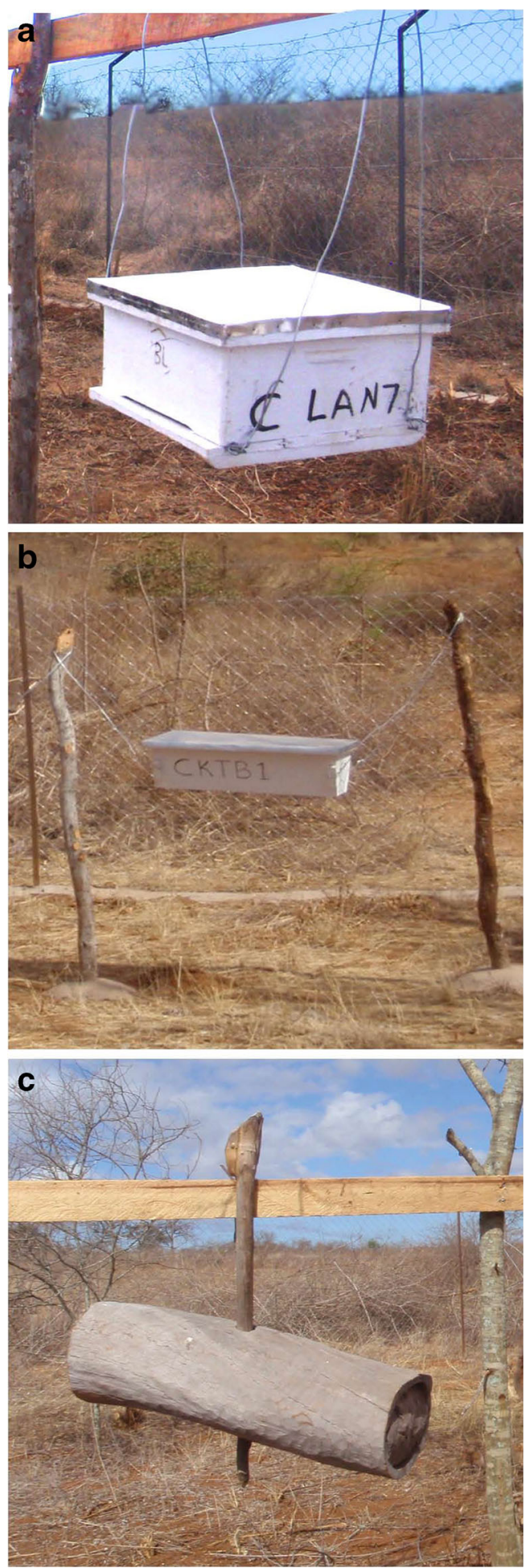
them beyond the reach of most rural Kenyans. Moreover, Log hives are much more durable and can be used for a much longer period of time (20 years) compared to the other two hive types (8 years) (personal communication with Kenyan beekeepers). Thus, despite the efforts and recommendations of beekeeping development groups, $96 \%$ of the reported hives in Kenya continue to be traditional Log hives (Hive Population and Production in Kenya, 2005, 2006, and 2007, Provincial Summaries).

While movable-frame hives allow for honey collection with minimal disturbance to the colony, there may be benefits to using Log hives that improve honey production for beekeepers over movable-frame hives, perhaps partly explaining the observed preference for Log hives. For example, colonies in Log hives may exhibit the lower parasite and pathogen loads, since previous studies found that bees in hives with rough interiors are more likely to coat the walls with propolis, which has known antimicrobial properties, resulting in reduced pathogen loads (Simone-Finstrom and Spivak 2012; SimoneFinstrom et al. 2010; Simone et al. 2009). Colonies with reduced parasite and pathogen loads may be less stressed, resulting in lower absconding rates, thereby also increasing the amount of honey available for beekeepers (Fletcher 1978; Hepburn and Radloff 1998).

In this study, we evaluated whether hive type (Log, Langstroth, and KTB) affected occupation rates by wild swarms, colony health (as measured by parasite and pathogen loads), and absconding rates across the wet and dry periods in Kenya. In addition to examining the effect of hive type, we also examined the associations between these different factors, to better understand the biology and behavior of honey bees in East Africa.

\section{MATERIALS AND METHODS}

\subsection{Apiary establishment}

In October 2012, three apiaries (A: S 01.31270 E $037.74574^{\circ}$ Elevation $1169 \mathrm{M}$, B: S01.32447 ${ }^{\circ} \mathrm{E}$ $037.76196^{\circ}$ Elevation $1171 \mathrm{M}$ and C: S 01.30129
E $037.76228^{\circ}$ Elevation $1206 \mathrm{M}$ ) were established on the South Eastern Kenya University (SEKU) campus located 40 kilometers west of Kitui, Kenya. The apiaries were within $2.5 \mathrm{~km}$ of each other and each was surrounded by a wire fence approximately $2.5 \mathrm{~m}$ in height. In total, 25 Langstroth (Lan) hives, 25 traditional log (Log) hives, and 25 Kenyan top-bar (KTB) hives, all locally constructed, were distributed in the three apiaries and left to be occupied by migrating swarms. Langstroth hives with a volume of $40 \mathrm{~L}$ were obtained from African Beekeepers Limited (Nairobi, Kenya) at a cost of Ksh 4500 (US\$48.80, March 15, 2015) per hive. As per typical practices in Kenya, they were outfitted with frames with starter strips of beeswax foundation, rather than full sheets of foundation. KTB hives with an approximate volume of $52.5 \mathrm{~L}$ were obtained from the International Centre of Insect Physiology and Ecology (icipe) at a cost of Ksh 3500 (US\$37.96) per hive. Following usual beekeeper practice, a small amount of beeswax was applied to all top bars. Applying beeswax to frames and top bars serves to make the hives more attractive to passing swarms and to provide the bees with "guidance" on where to construct combs to minimize the building of combs across frames and top bars. Log hives were constructed by Mulwa Mbithi, a beekeeper in Ukasi-Mwingi at a cost of Ksh 1000 (US\$10.84) per hive. They ranged in volume from 25 to $64 \mathrm{~L}$. The interior of the Log hives was rubbed with a ball of heated beeswax and propolis and smoked with the wood of "Mutanga" Scolopia zeyheri (Nees) Harv. as per traditional practices. See Figure 1 for more details about the hive types.

The average volume of the Log hives per apiary was $45 \pm 3.94,42 \pm 3.4$, and $39 \pm 3 \mathrm{~L}$, for apiaries $\mathrm{A}, \mathrm{B}$, and $\mathrm{C}$, respectively. There was no significant difference in average Log hive volume between apiaries (one-way ANOVA, $F_{\text {df:2,72 }}=0.61, P=0.55$ ), while Langstroth hives and KTB hives were constructed to consistent volumes of 40 and $52.5 \mathrm{~L}$, respectively. Eight hives of each type were randomly placed within each apiary except for one additional of each hive type placed in each apiary (apiary A had one additional Langstroth, B had one additional 
KTB, and $\mathrm{C}$ had one additional Log hive). At the beginning of the study, an automatic weather station was established at the SEKU. The HOBO U30-NRC Weather Station (Onset Computer, Bourne, MA) recorded the atmospheric pressure, rainfall, temperature, and relative humidity. Data was recorded per minute and later converted to daily maximum values.

\subsection{Collection of colony parameters and samples}

All apiaries and hives were inspected weekly to document hive occupation and absconding of previously established colonies. Routine data collection on established colonies began in early December 2012 and data were only gathered on colonies that had been established for at least 2 weeks to minimize absconding. Data collected on occupied hives included weight, the number of occupied frames (Lan and KTB only, since Log hives are not easily accessed), nest area (taken for colonies following absconding), and the presence and quantity of Varroa destructor mites. $V$. destructor mites were assessed using a standard sugar roll assay described in Ellis and Macedo 2001, using the standard half-cup to collect approximately 350 bees. Log hives were smoked from the rear and bees were collected at the front to increase the probability of collecting nurses (which have higher levels of mites) and minimize invasiveness. Our collection methods had no detectable effect on absconding, with only five recorded absconding events before June 2013.

Additionally, for each established colony, foragers were collected as they returned to the hive entrance with visible pollen loads. In total, 30 foragers/colony were collected twice a month on ice, stored at $-20^{\circ} \mathrm{C}$, and sent to the Pennsylvania State University for analysis of viral infection prevalence. Samples were stored in individual 2-mL cryogenic vials (VWR, Radnor, PA) in RNAlater (Life Technologies, Carlsbad, CA) or $95 \%$ ethanol. The protocol for screening for viruses was similar to that described in Muli et al. 2014, with some modifications (see Online Resource 1 for details). Briefly, abdomens of 20 bees per colony were pooled from one collection from April and one collection from June. Pooled abdomens were homogenized in either $600 \mu \mathrm{L}$ of TRI Reagent ${ }^{\circledR}$ (Sigma-Aldrich, St. Louis, MI) or QIAzol (Qiagen, Valencia, CA) using eight 2.0$\mathrm{mm}$ zirconia beads in a Fastprep instrument (Qbiogene, Montreal, Quebec). Whole RNA was extracted from the homogenates as per manufacturer's instructions, converted to cDNA, and screened for the presence of viruses using virusspecific primers (see Online Resource 2, Table S1).

\subsection{Data analyses}

All statistical analyses were performed using JMP® Pro 10 (SAS, Cary, NC) or R version 3.3.1. Data points were determined to be outliers if they were more than 3.5 standard deviations from the mean.

Hive occupation rates $\mathrm{We}$ evaluate the effect of hive type on occupation rate from the date of hive placement in the field, using a survival analysis. Log-rank tests were used for pairwise comparisons of the survival distributions of the occupation rates of the hive types. Survival analyses according to hive types were performed for all three apiaries pooled (Figure 2) and for each apiary separately (see Online Resource 3, Figure S1). Our threshold for statistical significance for this set of data is $P=0.017$ as per the calculation of the Bonferroni threshold ( $k=3$, threshold for whole model is $P=0.05$ ) for multiple comparisons of survival curves.

Analysis of viral infectionFor samples collected from the colonies in April and June, we screened for eight viruses in each colony (see Table S1 for a listing of viruses). We evaluated the prevalence of these viruses (proportion of colonies positive for a given virus) and the number of different viruses/ colony.

Pearson's chi-square was used to test whether infection prevalence differed between June and April (pooling data across all apiaries). A two-sample test for proportions was used to determine whether the number of different viruses detected in a colony was affected by collection date within apiaries and across hive types. 


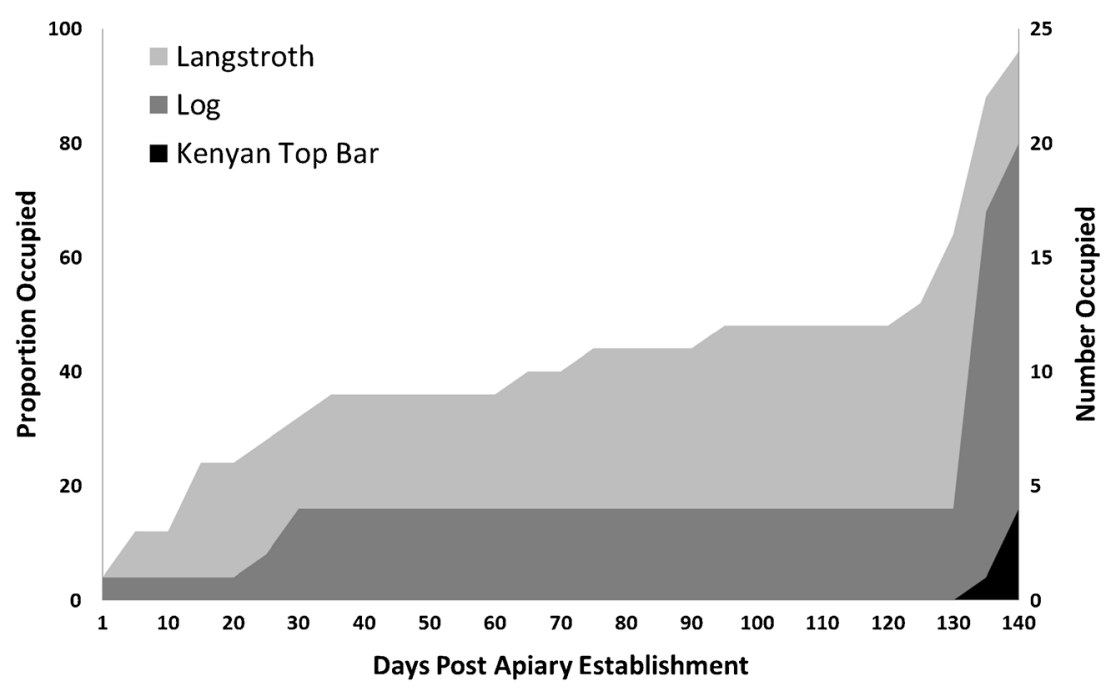

Figure 2. Effect of hive type on occupation rates. We examined the time (days post-hive placement) at which the different hive types were occupied by migrating colonies. Seventy-five total hive bodies were placed in three apiaries at the South Eastern Kenya University (SEKU) in October 2012. Data collection was completed when $100 \%$ of the Langstroth hives were occupied on April 9, 2013. Pairwise comparisons reveal that Langstroth hives were occupied most quickly, followed by Log hives, and lastly Kenyan top-bar hives (survival, log-rank: Lan vs $\log P<0.0027$, Lan vs KTB $P<0.001$, and $\log$ vs KTB $P<0.001$ ).

Effect of hive type, hive weight, and time on $\boldsymbol{V}$. destructor loads Mixed effect models were fit in $\mathrm{R}$ version 3.3.1 using package lme4 (Bates et al. 2015). Standard model selection procedures were followed. Briefly, the fullest model was fit first and random effect structure was optimized via REML estimation. Then, the most parsimonious fixed effect structure was chosen for our model that accounted for the most variation in our data. Our final model is summarized as follows:

$\log \left(y_{i}\right) \sim \operatorname{Gaussian}\left(\mu_{i}\right)$

$$
\begin{aligned}
\log \left(y_{i}\right)= & \beta_{0}+\beta_{1} \times \text { Hive. Weight }+\beta_{2} \\
& \times \text { Hive.TypeLan }+\beta_{3} \\
& \times \text { Hive.TypeLog }+\beta_{4} \\
& \times \text { Days.since.Occup }+\gamma_{j(i)}+\epsilon_{i}
\end{aligned}
$$

- $y_{i}=$ the count of mites per approximately 350 bees for $i$ th observation $i=1,2,3 \ldots, 219$.

- Hive.Weight $=$ weight of a colony at $i$ th observation.

- Hive. TypeLan $=1$ if observation $i$ was taken from a Lan hive, and 0 otherwise.

- Hive.TypeLog $=1$ if observation $i$ was taken from a Log hive, and 0 otherwise.

- Days.since. Occup = a numerical vector corresponding to how many days since a hive was occupied by a swarm that observation $i$ was made.

Here, $\gamma_{j(i)}$ is the random effect for colony, chosen because we resampled the same hives over time, and therefore time points were necessarily dependent on one another. We assumed random effects and errors are normally distributed about a mean of $0\left(\gamma_{j(i)} \sim N\left(0, \sigma_{\text {hive }}^{2}\right), \epsilon_{i} \sim N\left(0, \sigma^{2}{ }_{y}\right)\right)$ and that $\gamma_{i(j)}$ and $\epsilon_{i}$ are independent for all $j=1,2, \ldots, 60, i=1,2,3, \ldots, 219$.

Analysis of absconding rates We next wanted to where: 
number of occupied frames) or weight had any effect on whether or not a colony absconded. The number of occupied frames for each hive was first transformed by taking the $\log _{10}$ of the count data. Then, the transformed data were subjected to a Wilcoxon rank-sum with an approximation of a chi-square distribution.

Next, a one-sided $t$ test was used to test the hypothesis that remaining colonies would on average weigh more, and binomial regression was used to test whether there was an association between the weight of a colony and the probability that they would abscond. A binomial regression was also used to test whether the date of occupation of the hive (and thus the age of the colony) was associated with the probability of a hive absconding in July or August of 2013.

Since absconding peaked just after June, we also determined if there was a correlation between viral infection levels and $V$. destructor levels in June and subsequent absconding behavior. First, a twosample test for proportions was used to test for a relationship between absconding and infection with more than one virus, given that every hive had at least one virus. Second, mite count data were log-transformed and tested for a relationship with absconding status with a Wilcoxon rank-sum test. Further, the effect of location (apiary) on absconding rates was assessed using Pearson's chi-square.

\section{RESULTS}

\subsection{Environmental patterns in study site}

Based on temperature and rainfall patterns, it was possible to distinguish five periods with distinct weather patterns during this study (see Figure S2). These weather periods could be classified as high temperature and no rainfall (January and February), high temperature and very high rainfall (March and April), lower temperature and low rainfall (May, June, and July), high temperature and no rainfall (August-September), and lower temperature and low rainfall/short rains (October, November, and December).

\subsection{Effect of hive type and apiary location on hive occupation rates}

Though hives were placed in apiaries in October 2012, there was only a marked increase in occupation of all hives in early April 2013 (Figure 2, around day 135 post hive placement) corresponding directly with the middle of the reproductive swarming season (March-May) and high temperature/high rainfall weather period in the Kitui region of Kenya. By 141 days post hive placement, corresponding to 9 April 2013, all Langstroth hives were occupied by swarms; therefore, this date was chosen as the end point for the analysis of occupation rates. At this end point, 20 (80\%) of all Log hives were occupied and only 4 $(16 \%)$ of the KTB hives were occupied. There were no absconding events in April and only four absconding events in mid-March 2013, indicating observed occupation events were new migratory swarms and not swarms absconding from their initial hive and occupying a new one within the same apiary. Pairwise comparisons confirmed that Langstroth hives were occupied most quickly, followed by Log hives, and lastly KTB hives (survival, log-rank: Lan vs $\log P<0.0027$, Lan vs KTB $P<0.001$, and $\log$ vs KTB $P<0.001)$. Similar results were obtained if each apiary is analyzed separately (see Figure S1 and supplemental for statistics).

\subsection{Effect of hive type, weather period, and apiary location on viral prevalence and number of detected viruses}

April was chosen as a representative month for the first wet period that the colonies experienced, while June corresponded to the first dry period that the colonies experienced. All colonies were tested for the presence of eight viruses in April and June (see Table S1 for a listing of viruses and Table S2 for a listing of virus infections in each colony at each time point). In April, 50.4\% of all colonies were infected with at least one virus. In June, there was a significant increase in the percentage of colonies infected with viruses, with $100 \%$ of colonies infected with at least one virus (Pearson's chi-square, $\chi^{2}=22.501$, df $=1$, $P<0.0001)$. 
In April, there were no significant differences among the three hive types in either the prevalence, defined as the proportion of infected colonies (Pearson's chi-square, $\chi^{2}=1.061$, df $=49$, $P=0.59$ ), or numbers of different viruses/colony (Pearson's chi-square, $\chi^{2}=2.845$, df $=49$, $P=0.58$ ). For June, all hives had at least one virus, and there was no difference in the numbers of viruses/colony among hive types (Pearson's chi-square, $\chi^{2}=2.154$, df $\left.=45, P=0.71\right)$. There was a significant increase in viral prevalence from April to June for both the Langstroth and Log hives, but the difference was not significant for the KTB hives, likely due to the small sample size (Figure 3; two-sample test for proportions with continuity correction, $\mathrm{df}=1$; KTB $P=0.207, \operatorname{Lan} P=0.0007, \log P=0.0007$ ).

When comparing across the three apiaries, apiary $\mathrm{C}$ had the lowest number of infected colonies in April, but $100 \%$ of the colonies in apiary C were infected by June. Within each individual apiary, there was an increase in infection prevalence from April to June, but this was only significant for apiary $\mathrm{C}$ (two-sample test for proportions with continuity correction, $\mathrm{df}=1$; apiary A: $P=0.25$, apiary $\mathrm{B}: P=0.082$, apiary $\mathrm{C}$ : $P<0.001)$.

In April, BQCV was the most prevalent virus, as it was found in $48.38 \%$ of infected colonies. However, we also detected one colony infected with DWV-A, one colony infected with SBV, and four colonies infected with DWV-B (formerly VDV-1(Mordecai et al. 2015)) in April. In June, DWV-A was the most prevalent with $97.5 \%$ of all colonies infected, followed by $52.5 \%$ of colonies having $\mathrm{BQCV}$, while one colony was infected with $\mathrm{ABPV}$ and five colonies were infected with DWV-B. In no instance did we detect CBPV, KBV, or IAPV. See Table S2 for a compilation of all viruses detected in all colonies.

\subsection{Effect of hive type, hive size, and time on $V$. destructor levels}

The levels of $V$. destructor in June were not different between hive types (Wilcoxon rank sums, $\chi^{2}=2.1$, df $=2, P=0.35$ ) or apiaries (Wilcoxon rank sums, $\chi^{2}=2.94$, df $=2$, $P=0.23$ ). The log mite loads were linearly associated with time after accounting for hive weight and hive type (Figure 4: linear mixed effect model, $F_{\text {df:1,216 }}=49.72$, fixed effects: hive weight, hive type, and days since a colony occupied the hive, random effect $=$ hive, marginal $R^{2}=0.2$, conditional $R^{2}=0.38$ ). We estimate that median mite counts increased multiplicatively by 1.0039 times per day elapsed (two-tailed $t$ test, $t=7.052$, $\mathrm{df}=216, P=2.38 \times 10^{-11}, 95 \%$ CI 1.0034 $1.0044)$.

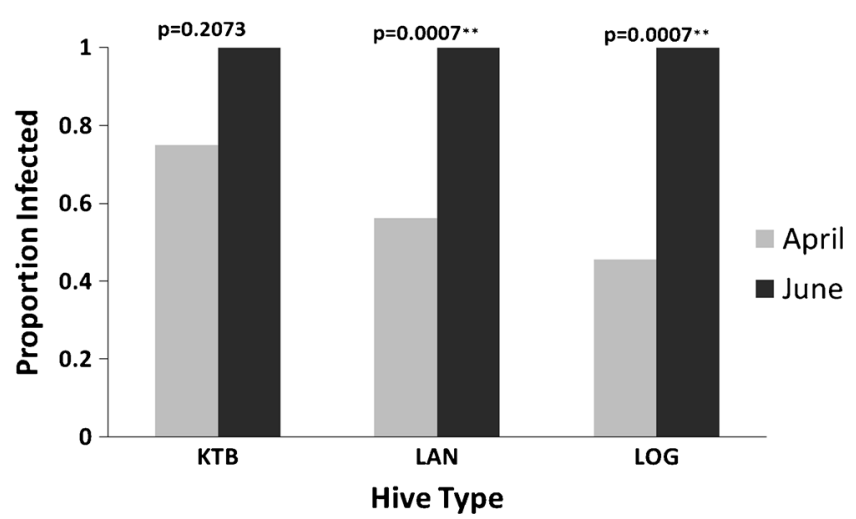

Figure 3. Effect of weather period and hive type on proportion of infected colonies (viral prevalence). April was chosen as a representative month for the first wet period that the colonies experienced, while June corresponded to the first dry period month that the colonies experienced. While there was a general trend for higher prevalence of infection in June in all hive types, the difference was only significant in Langstroth and Log hives, likely due to the small number of KTB hives in the study (two-sample test for proportions, $\mathrm{df}=1$; KTB $P=0.2073$, Lan $P=0.0007$, $\log P=0.0007$ ). 


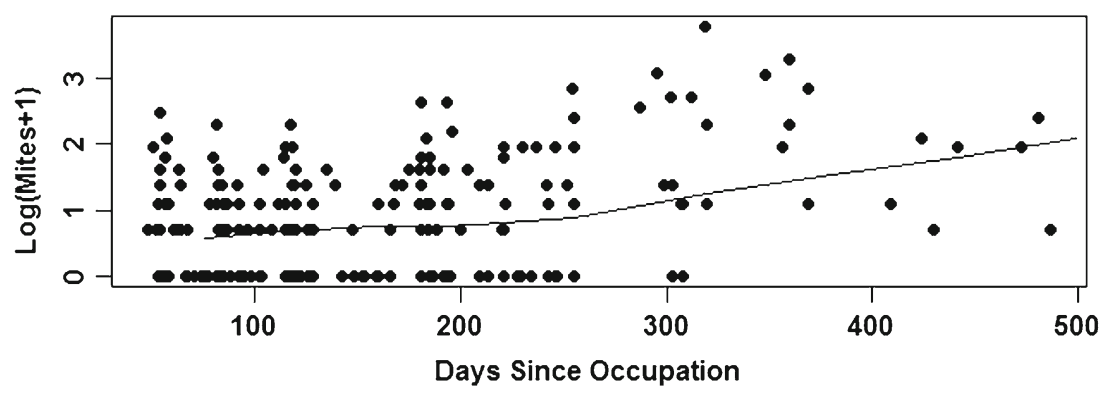

Figure 4. $\log _{10}$ average V. destructor load over time. Apiaries were established in October 2012 and measurements started in December 2012 to avoid disturbing young colonies. There was a clear linear relationship between log mite counts and time after accounting for hive weight and hive type, suggesting that mites are accumulating over the life span of the colony (linear mixed effect model, AIC $=503.51, F=46.743$ on 1 and $216 \mathrm{df}$, fixed effects: hive weight, hive type, and days since colony occupation, random effect $=$ hive, marginal $R^{2}=0.2$, conditional $R^{2}=0.376$ ). Line drawn is an estimated smoother for the additive mixed effect model.

\subsection{Effect of $V$. destructor levels in viral infections}

In contrast to recent studies in northern Europe (Francis et al. 2013), New Zealand (Mondet et al. 2014), Hawaii (Martin et al. 2012), and Kenya (Muli et al. 2014), there was no relationship observed between $V$. destructor loads and the viral diversity (number of viruses) found in colonies during April (Figure S3, SLR, $F_{\text {df: } 1,26}=0.0868$, $P=0.77, R^{2}=0.0033$ ) or June (SLR, $\left.F_{\text {df: } 1,38}=0.5464, P=0.463, R^{2}=0.014\right)$.

\subsection{Factors impacting absconding rates}

There was a marked increase in absconding in July and August 2013, which corresponds to the hot, dry period in Kenya. We labeled colonies that absconded in July-September as "absconding colonies" and those that did not abscond as "remaining colonies." We then examined colony occupation date, colony size (as determined by the number of occupied frames), colony weight, the numbers of different viruses/colony, and $V$. destructor levels of these colonies in June (the start of the dry period) to determine if there were any significant differences in these parameters between absconding and remaining colonies.

Remaining colonies had significantly more occupied frames in June (one-way Wilcoxon rank sums, chi-square approximation, $\chi^{2}=5.642, \mathrm{df}=1$, $P=0.018)$ and were on average heavier in June than colonies that did abscond (one-sided $t$ test, $t=2.996, \mathrm{df}=44, P=0.0022,95 \%$ CI $3.45-$ $17.7 \mathrm{lbs})$. Indeed, even after accounting for hive type and apiary, remaining colonies were on average heavier than absconding colonies (binomial regression, $t=-2.34, \mathrm{df}=40, P=0.019, R^{2}=0.511$ ).

The date of occupation had no effect on whether or not a colony absconded (logistic fit, chisquare approximation, $\chi^{2}=0.863, \mathrm{df}=1$, $P=0.35$ ). There was no significant difference between absconding and remaining colonies in the number of viruses (Figure 5a; two-sample test for proportions with continuity correction, $\left.\chi^{2}=0.447, \mathrm{df}=1, P=0.504\right)$ or $V$. destructor mite levels (Figure 5b; Wilcoxon rank sums, $W=223.5, \mathrm{df}=4, P=0.48)$ in June.

Additionally, the three apiaries exhibited significant differences in levels of absconding (Pearson's chi-square, $\chi^{2}=8.818, \mathrm{df}=2, P=0.012$ ). There were no differences in absconding between apiaries $\mathrm{A}$ and $\mathrm{B}$ (two-sample test for equality of proportions with continuity correction, $\chi^{2}=0.3, \mathrm{df}=1$, $P=0.58$ ) but apiary $\mathrm{C}$ had significantly higher absconding rate than either A or B (two-sample test for equality of proportions with continuity correction, $\chi^{2}=4.055$ and 8.04 , and $P=0.044$ and 0.0046 , respectively, $\mathrm{df}=1$ ).

\section{DISCUSSION}

Overall, our data suggested Langstroth hives are the most attractive to migrating swarms and 

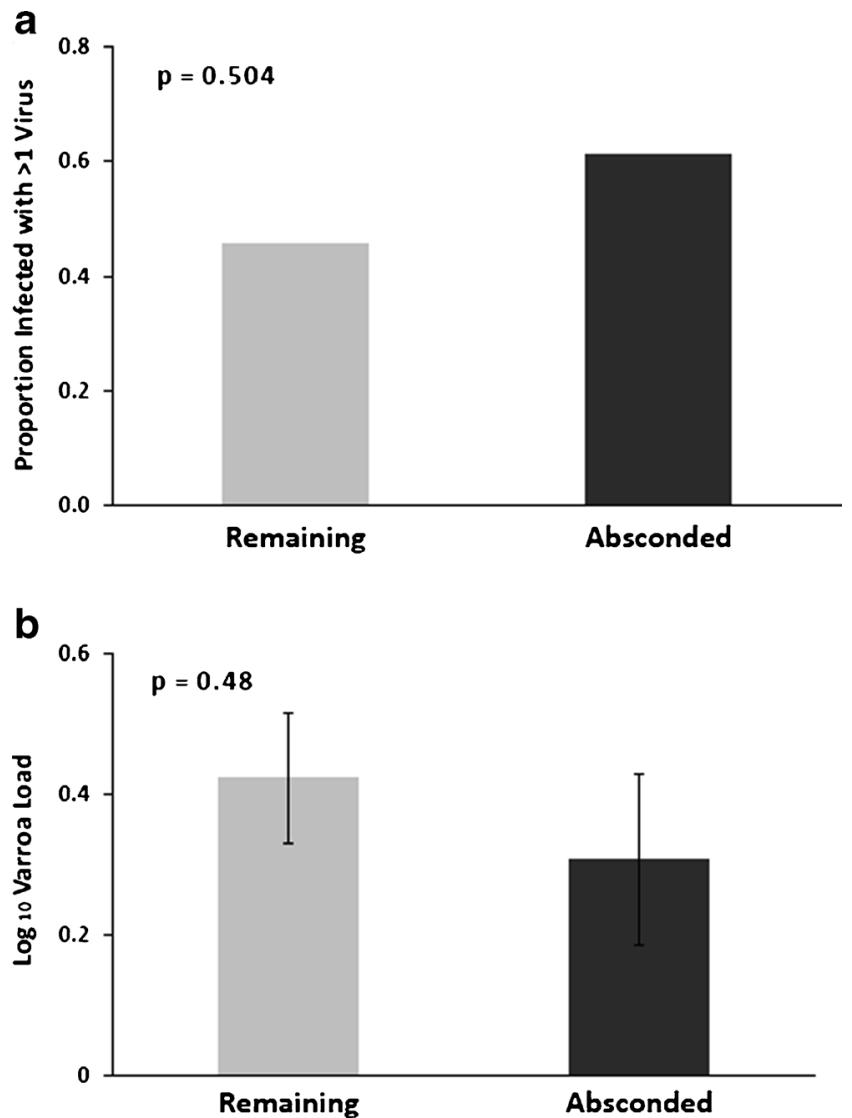

Figure 5. Effect of pathogen and parasite infection levels on absconding rates. a All colonies in June 2013 were infected with at least one virus and several were infected with multiple viruses (see Table S2). Colonies that absconded in July or August 2013 were not infected with more types of viruses in June than those that did not abscond (two-sample test for equality of proportions with continuity correction, $\mathrm{df}=1, P=0.504$ ). $\mathbf{b}$ Whether a colony absconded in July or August had no relationship with its $V$. destructor loads in June (Wilcoxon rank sums, $W=223.5, \mathrm{df}=4, P=0.48$ ).

KTB hives are the least attractive, but otherwise there was no variation among the hive types in any of the other parameters we tested. Levels of $V$. destructor mites and the prevalence of viral infections increased over time (from April to June) but did not differ between hive types. Indeed, $V$. destructor levels increased linearly with time even after accounting for hive type and hive weight and random effects associated with resampled colonies. Colonies were significantly less likely to abscond during the dry period if they had occupied more frames and weighed more by June, and there was variation in absconding rates across locations, but again, there was no effect of hive type.

More detailed studies are necessary to understand why the swarming colonies preferred Langstroth hives and very clearly did not prefer KTB hives. All the hives contained wax, which serves as an attractant for swarming colonies. Because we were following standard procedures for beekeepers in these areas, the Langstroth hives likely had larger amounts of wax than the other types of hives (see Section 2). Previous studies have demonstrated that cavity volume can impact hive attractiveness to swarming bees for European honey bee stocks in the USA, with European 
honey bees preferring cavity sizes of $40 \mathrm{~L}$ over larger and smaller sizes (Seeley and Morse 1976, 1978). For our hives, the KTB hives were considerably larger $(52.5 \mathrm{~L})$ than the Langstroth and Log hives ( $\sim 40 \mathrm{~L})$. However, a previous study of Africanized stocks of bees in the USA found they preferred cavity sizes of 31 to $24 \mathrm{~L}$ (Schmidt and Thoens 1987). Another study of Africanized bees in Venezuela found Africanized bees preferred $80 \mathrm{~L}$ cavities over smaller sizes (Rinderer et al. 1981), while other studies showed no preferences among cavities ranging in size from 13.5 to $31 \mathrm{~L}$ (Schmidt and Hurley 1995) or even 20 and 120 L (Rinderer et al. 1982). Furthermore, cavity shape does not seem to influence cavity selection by European or Africanized honey bees (Schmidt and Thoens 1992). Thus, it is unclear why the KTB hives were the least preferred in our study, highlighting the need for more detailed behavioral work using honey bees in Africa to determine which aspects of the hive body are attractive to these populations.

$V$. destructor loads and viral prevalence correlated with weather period and/or colony age but were not associated with hive type or location (Figures 4 and 5). It is unsurprising that we found no association with hive type and $V$. destructor loads given recent studies suggesting colonies in close proximity to one another are at higher risk for sharing mites (Nolan and Delaplane 2016; Seeley and Smith 2015). That the present study found no association between $V$. destructor and viral diversity is likely due to the relatively few viruses we detected. Additionally, stress factors not measured may account for the observed increase in viral prevalence in June. $V$. destructor vectors many viruses and $V$. destructor parasitization can increase viral titers (reviewed in McMenamin and Genersch 2015). V. destructor reproduces in honey bee brood cells, and therefore, mite production coincides with honey bee brood production (Boot et al. 1994; Calis et al. 1999; Fuchs and Langenbach 1989). Breaking the brood cycle through swarming or absconding thus can limit $V$. destructor infestation (Hood 2000; Loftus et al. 2016; Ruppert 2011). Thus, allowing Kenyan honey bee colonies to abscond and migrate (which is a standard part of the colony life cycle in Log hives) may help reduce the loads of
V. destructor mites and pathogens in honey bee populations. Overall, our results suggest that in Kenyan honey bee populations, $V$. destructor infestation is not associated with increased viral diversity - in contrast to Muli et al. 2014-or higher rates of absconding and thus does not appear to be overtly negatively impacting the colonies in our study. This, taken with the fact that $V$. destructor loads increased over the course of the study, may suggest that Kenyan honey bees are tolerant to this parasite, in contrast to the results found in South Africa suggesting that A. mellifera scutellata was resistant rather than tolerant to $V$. destructor (Strauss et al. 2015a). Further studies are needed to test this hypothesis in Kenyan honey bees and should similarly evaluate $V$. destructor population growth rates in Kenyan colonies, as well as hygienic behaviors potentially associated with response to mite infestation (Allsopp 2006; Strauss, Pirk et al. 2016). Interestingly, a recent study suggests that acaracide treatments, which can be quite expensive, are minimally beneficial in South African A. mellifera scutellata colonies (Strauss et al. 2015b), suggesting miticide treatments may be of limited utility to African beekeepers.

In our study, the likelihood that a colony will abscond during a period of reduced forage appears to be influenced primarily by colony size rather than infection levels, parasitization levels, hive type, or time since colony establishment. This is consistent with previous reports of African honey bees showing resilience to introduced parasites and diseases (Muli et al. 2014; Mumoki et al. 2014; Pirk et al. 2014, 2016; Strauss et al. 2015a). In our study, larger and heavier colonies were significantly less likely to abscond. These results are consistent with the findings of Winston and colleagues for Africanized honey bee stocks in French Guiana, South America (Winston et al. 1979). They found that Africanized colonies with fewer stored resources were more likely to respond to a reduced nectar flow by absconding, which could not be prevented by feeding sugar water. Thus, they hypothesized that the more important factor in the hive's decision to abscond is likely nectar flow as opposed to honey stored (Winston 1993). In contrast, Schneider and McNally found that absconding/migrating 
colonies of A. mellifera scutellata in Botswana had larger food stores and population sizes than non-migrating colonies, 4-6 weeks prior to starting migration preparation (Schneider and McNally 1992). It is possible that the differences between the studies are due to the timing of the colony assessments: perhaps, the larger colonies prepared for absconding/migration early by reducing brood production (in preparation for migration, queens will cease egg-laying, reviewed in Grozinger et al. 2014), which would result in a smaller colony size at a later time point. While it is possible that we failed to observe migration preparation, this is unlikely since the data on colony size were collected at least 4 weeks prior to most of the absconding events. Thus, based on our results and Winston 1979, beekeepers should be able to reduce absconding by placing apiaries in areas with sufficient floral resources and nutrition, though supplemental feeding with sugar water may be of limited benefit. However, both absconding and swarming may serve as a valuable mechanism for breaking the brood cycle and reducing populations of brood parasites and pathogens.

Determining which hive type is best for Kenyan beekeepers requires a comprehensive comparison of the costs and benefits over multiple years of use by a diversity of beekeepers (with varying levels of experience) to fully assess the longevity of the equipment and productivity under standard conditions. Log hives are the least expensive option, last the longest ( $\sim 20$ years, according to Kenyan beekeepers), and do not require a high degree of knowledge to manage or specialized extraction equipment to collect the honey. In contrast, Langstroth hives are significantly more expensive, require high-quality wood and attention to detail in construction (to maintain bee space) and a higher level of knowledge to manage (adding supers, use of queen excluders, maintaining bee space, etc.), and need to be more frequently replaced (every 8 years, personal communication with Kenyan beekeepers). Additionally, to achieve the maximum economic benefit, this approach relies on expensive extracting equipment to collect honey and allow for reusing wax combs, though obviously combs could be collected and destroyed in a manner similar to Log hives. KTB hives, as their design intended (Gentry 1982), are intermediate in cost and have ease of production and management but like Langstroth are short-lived compared to Log hives, according to local Kenyan beekeepers. When properly managed, KTB hives produce more honey than Log hives in Ethiopia (Yirga and Teferi 2010) and Kenya (Mulindo et al. 2008), while Langstroth hives are more productive than KTB hives (Beyene et al. 2015; Gebremedhn and Estifanos 2013), except, perhaps, in more arid regions (Mulindo et al. 2008).

While KTB hives appear to be a reasonable compromise between Log and Langstroth hives, this can only be so if issues related to swarm attractiveness (this study), thermoregulation (Gichora 2003), and honey harvesting (Mulindo et al. 2008) can be addressed. In our study, KTB hives were significantly less attractive to swarms compared to the two other hive types, and it remains to be determined which aspect of the hive construction reduced attractiveness. Furthermore, high equatorial temperatures are also a challenge when using KTB hives (Gichora 2003), and it has been recommended that KTB hives be placed in shade and/or using a soft timber insulation beneath a painted white corrugated iron cover. Recently, a new design of the KTB hive has included a dividing board that can adjust the cavity size to accommodate a growing colony (Mulindo et al. 2008). This would allow the beekeeper to remove honey more easily and potentially improve thermoregulation.

Beekeeping in East Africa involves integrating information about the natural history and behavior of African honey bees, developing economically viable management strategies, and adjusting approaches to mitigate emerging challenges, such as the introduction of $V$. destructor mites and climate change. This study takes the first steps in evaluating the role of hive type on honey bee colony performance and health, and our results suggest that all three hive types likely have a place in Kenyan/East African beekeeping and the type of hive an individual chooses to use may ultimately depend on his/her financial resources, level of skill/knowledge, and personal preference. The health of honey bee populations in Kenya may be more dependent on current low intervention 
practices (i.e., not chemically treating for $V$. destructor mites, allowing colonies to abscond and migrate, and low colony density) and thus these practices should be continued.

\section{ACKNOWLEDGEMENTS}

This study was funded by a National Science Foundation-BREAD grant (0965441) to J. Tumlinson, M. Frazier, J. Frazier, C. Grozinger, D. Masiga, E. Muli, and H. Patch. A. McMenamin also received support from the Penn State Discovery Grant Program and the Goldwater Foundation.

Contributions CG, EM, JT, MF, DM, and HP conceived this research and designed the experiments. AM, FM, MF, JK, BM, TB, HP, BT, DM, and EM performed the experiments and analyses. All authors wrote, read, and approved the manuscript.

L'impact du type de ruche sur le comportement et la santé des colonies d'abeilles (Apis mellifera) au Kenya

mode de conduite apicole / pathogène / apiculture en milieu rural / Afrique / désertion de la ruche

Der Einfluss des Beutentyps auf das Verhalten und die Gesundheit von Honigbienenvölkern ( Apis mellifera) in Kenia

Bienenhaltung / Haltungspraxis / Pathogene / ländliche Bienenhaltung / ausreissender Schwarm

\section{REFERENCES}

Adjare S. O. (1990). Traditional and modern behives and beekeeping equipment. Retrieved from http://www. fao.org/docrep/t0104e/T0104E07.htm

Allsopp M. (2006). Analysis of Varroa destructor infestation of southern African honeybee populations. University of Pretoria.

Bates D., Maechler M., Bolker B., Walker S. (2015). Fitting linear mixed-effects models using lme4. J. Stat. Softw., 67(1), 1-48. https://doi.org/doi:10.18637/jss.v067.i01

Beyene T., Abi D., Chalchissa G., Mekonen W.M. (2015). Evaluation of transitional and modern hives for honey production in the Mid Rift Valley of Ethiopia. Global Journal of Animal Scientific Research, 3(1), 48-56.

Boot W. J., Sisselaar D. J. A., Calis J. N. M. (1994). Factors affecting invasion of Varroa jacobsoni (Acari: Varroidae) into honeybee, Apis mellifera (Hymenoptera: Apidae), brood cells. Bull. Entomol. Res., 84, 003-010.

Calis J. N. M., Fries I., Ryrie S. C. (1999). Population modelling of Varroa jacobsoni Oud. Apidologie, 30, 111-124.

Crane E. (1999). The world history of beekeeping and honey hunting. New York: Routledge.

Ellis M. D., Macedo P. A. (2001). Using the sugar roll technique to detect Varroa mites in honey bee colonies using the sugar roll technique to detect Varroa mites in honey bee colonies. Retrieved from http://digitalcommons.unl.edu/extensionhist/1173

Fletcher D. J. C. (1978). The African bee, Apis mellifera adansonii, in Africa. Annu. Rev. Entomol., 23, 151-171.

Francis R. M., Nielsen S. L., Kryger P. (2013). Varroa-virus interaction in collapsing honey bee colonies. PLoS One, 8(3), e57540. https://doi.org/10.1371/journal. pone. 0057540

Fuchs S., Langenbach K. (1989). Multiple infestation of Apis mellifera L. brood cells and reproduction in Varroa jacobsoni Oud. Apidologie 20, 257-266

Gebremedhn, H., Estifanos, A. (2013). On farm evaluation of Kenyan Top bar hive (KTBH) for honey production in Tigray Region, Northern Ethiopia. Livestock Research for Rural Development, 25(5).

Gentry C. (1982). Small scale beekeeping. Peace Corps.

Gichora M. (2003). Towards realization of Kenya's full beekeeping potential: a case study of Baringo District. (P. Vleck, M. Denich, C. Martius, \& N. van de Giesen, Eds.).

Grozinger C. M., Richards J., Mattila H. R. (2014). From molecules to societies: mechanisms regulating swarming behavior in honey bees (Apis spp.). Apidologie, 45(3), 327-346.

Hepburn H. R., Radloff S. E. (1998). Honeybees of Africa. New York: Springer.

Hood M. (2000). Entomology insect information series: Varroa mite control. Clemson.

Kasina M., Kraemer M., Martius C., Wittmann D., Wittmann D. (2009). Diversity and activity density of bees visiting crop flowers in Kakamega, Western Kenya. J. Apic. Res., 48(2), 134-139.

Loftus J. C., Smith M. L., Seeley T. D. (2016). How honey bee colonies survive in the wild: testing the importance of small nests and frequent swarming. PLoS One, 11(3), 1-11. https://doi.org/10.1371/journal. pone. 0150362

Macharia J., Raina S. K., Muli E. (2010). Stingless beekeeping: an incentive for rain forest conservation in Kenya. Wolfville: Science and Management of Protected Areas Association.

Martin S. J., Highfield A. C., Brettell L., Villalobos E. M., Giles E., Powell M., Nikaido S., Schroeder D. C., Budge G. E. (2012). Global honey bee viral landscape altered by a parasitic mite. Science, 336(6086), 1304 6. https://doi.org/10.1126/science.1220941

Mbae R. M. (1999). Overview of beekeeping development in Kenya. (S. K. Raina, E. N. Kioka, \& S. W. Mwanycky, Eds.). Nairobi: ICIPE Science Press. 
McMenamin A. J., Genersch E. (2015). Honey bee colony losses and associated viruses. Curr. Opin. Insect Sci., 8, 121-129. https://doi.org/10.1016/j. cois.2015.01.015

Mondet F., de Miranda J. R., Kretzschmar A., Le Conte Y., Mercer A. R. (2014). On the front line: quantitative virus dynamics in honeybee (Apis mellifera L.) colonies along a new expansion front of the parasite Varroa destructor. PLoS Pathog., 10(8), e 1004323. https://doi.org/10.1371/journal.ppat.1004323

Mordecai G. J., Brettell L. E., Martin S. J., Dixon D., Jones I. M., Schroeder D. C. (2015). Superinfection exclusion and the long-term survival of honey bees in Varroa-infested colonies. ISME J., 10(October), 1-10. https://doi.org/10.1038/ismej.2015.186

Muli E., Patch H., Frazier M., Frazier J., Torto B., et al. (2014). Evaluation of the distribution and impacts of parasites, pathogens, and pesticides on honey bee (Apis mellifera) populations in East Africa. PLoS One, 9(4), e94459. https://doi.org/10.1371/journal.pone.0094459

Mulindo J. C., J.J.D., Fabian M., Chesang S. K. (2008). Honey production in dry hot areas. Nairobi.

Mumoki A. F. N., Fombong A., Muli E., Muigai A. W. T., Masiga D. (2014). An inventory of documented diseases of African honeybees. Afr. Entomol., 22(3), 473-487.

Nolan M. P., Delaplane K. S. (2016). Distance between honey bee Apis mellifera colonies regulates populations of Varroa destructor at a landscape scale. Apidologie, 8-16. https://doi.org/10.1007/s13592016-0443-9

Ntenga G. M., Mgongo B.t. (1991). Honey hunters and beekeepers: a study of traditional beekeeping in Babati District, Tanzania. Swedish University of Agricultural Sciences,International Rural Development Centr.

Pirk C., Human H., Crewe R., VanEngelsdorp D. (2014). A survey of managed honey bee colony losses in the Republic of South Africa-2009 to 2011. J. Apic. Res., 53(1), 35-42. https://doi.org/10.3896 /IBRA.1.53.1.03

Pirk C., Strauss U., Yusuf A. A., Démares F. (2016). Honeybee health in Africa-a review. Apidologie, 47, 276-300

Rinderer T. E., Collins A. M., Bolten A. B., Harbo J. R. (1981). Size of nest cavities selected by swarms of Africanized honeybees, Apis mellifera, in Venezuela. J. Apic. Res., 20(3), 160-164.

Rinderer T. E., Tucker K. W., Collins A. M. (1982). Nest cavity selection by swarms of European and Africanized honeybees. J. Apic. Res., 21(2), 98-103.

Ruppert N. (2011). Options for Varroa mite control. North Carolina Department of Agriculture and Consumer Services. Retrieved from https://growingsmallfarms. ces.ncsu.edu/wp-content/uploads/2014/12/VARROAMITE-CONTROL-2013.pdf?fwd=no

Schmidt J. O., Hurley R. (1995). Selection of nest cavities by Africanized and European honey bees. Apidologie, 26, 467-475.
Schmidt J. O., Thoens S. C. (1987). Swarm traps for survey and control of Africanized honey bees. Bull. ESA, 155-158. https://doi.org/http://dx.doi.org/10.1093 /besa/33.3.155

Schmidt J. O., Thoens S. C. (1992). Criteria for nest site selection in honey bees (Hymenoptera: Apidae): preferences between pheromone attractants and cavity shapes. Physiol. Chem. Ecol., 21(5), 1130-1133.

Schneider S. S., McNally L. C. (1992). Factors influencing seasonal absconding in colonies of the African honey bee, Apis mellifera scutellata. Insectes Soc., 39, 403423.

Seeley T. D., Smith M. L. (2015). Crowding honeybee colonies in apiaries can increase their vulnerability to the deadly ectoparasite Varroa destructor. Apidologie, 46(6), 716-727.

Seeley T., Morse R. (1976). The nest of the honey bee (Apis mellifera L.). Insectes Soc., 23(4), 495-512.

Seeley T., Morse R. (1978). Nest site selection by the honey bee, Apis mellifera. Insectes Soc., 25(4), 323-337.

Simone-Finstrom M. D., Spivak M. (2012). Increased resin collection after parasite challenge: a case of self-medication in honey bees? PLoS One, 7(3), e34601. https://doi.org/10.1371/journal. pone. 0034601

Simone-Finstrom M., Gardner J., Spivak M. (2010). Tactile learning in resin foraging honeybees. Behav. Ecol. Sociobiol., 64(10), 1609-1617.

Simone M., Evans J. D., Spivak M. (2009). Resin collection and social immunity in honey bees. Evolution, 63(11), 3016-22.

Strauss U., Dietemann V., Human H., Crewe R., Pirk C. W. W. (2015a). Resistance rather than tolerance explains survival of savannah honeybees (Apis mellifera scutellata) to infestation by the parasitic mite Varroa destructor. Parasitology, 114. https://doi.org/10.1017/S0031182015001754

Strauss U., Pirk C. W. W., Crewe R. M., Human H., Dietemann V. (2015b). Impact of Varroa destructor on honeybee (Apis mellifera scutellata) colony development in South Africa. Exp. Appl. Acarol., 65(1), 89106.

UNDP-Kenya. (2008). Innovation for sustainable development: local case studies from Africa. United Nations.

Wilson R. (2006). Current status and possibilities for improvement of traditional apiculture in sub-Saharan Africa. Livest. Res. Rural Dev., 18(111).

Winston M. (1993). Killer bees. Cambridge: Harvard University Press.

Winston M., Otis G. W., Taylor O. R. (1979). Absconding behavior of the Africanized honeybee in South America. J. Apic. Res., 18, 85-94.

Yirga, G., Teferi, M. (2010). Participatory Technology and Constraints Assessment to Improve the Livelihood of Beekeepers in Tigray Region, northern Ethiopia. Momona Ehiopian Journal of Science, 2(1), 76-92. 